\title{
29. BITUMINOLOGICAL STUDIES OF THE SAMPLES FROM SITE 379 AND LABORATORY SIMULATION OF DISPERSED ORGANIC MATTER TRANSFORMATION ${ }^{1}$
}

\author{
A.A. Geodekyan, G.F. Ul'mishek, T.G.Tcherova, V.I. Avilov, A.P. Bokovoy, \\ Z.I. Verkhovskaya, and M.S. Fedorova, \\ P.P. Shirshov Institute of Oceanology, USSR Academy of Sciences, 1, Letnyaya, Lublino, Moscow, USSR
}

\section{INTRODUCTION}

The studies of bitumoids from the Black Sea sediments are of great interest because these sediments are regarded by most geologists as recent analogs of the oil-producing facies of the past. The analyses of 23 samples from the cores taken at Site 379 were made at the Laboratory of Oil and Gas Prospecting of the Sea Regions of the P. P. Shirshov Institute of Oceanology, the USSR Academy of Sciences. A list of the samples is given in Table 1. Five samples were analyzed in triplicate, two samples were stored in a special fluorine plastic capsule for further laboratory simulation of the oil and gas formation processes. Such simulation, though not giving a full reproduction of the complicated natural processes, makes it possible to evaluate the trend of a catagenic transformation of dispersed organic matter and to study the products generated during the experiment.

\section{CHARACTERISTICS OF BITUMOID "A"}

\section{Experimental Methods and Procedure}

Bitumoid " $\mathrm{A}$ " was extracted from the sediment by a consecutive extraction with chloroform (chloroform bitumoid "A" - $\mathrm{A}_{\text {chl }}$ ) and alcohol-benzene (alcoholbenzene bitumoid " $A$ " - $A_{\text {alb }}$ ).

The fractional composition of the bitumoids (6-15 mg) was determined by absorption chromatographic analyses on silica gel columns (AKS, acid washed, 100$200 \mathrm{mesh}$; dimensions $15 \mathrm{~cm} \times 0.5 \mathrm{~cm}$ ). Solvent was removed from the eluting fractions with a nitrogen stream.

Elution was carried out first with hexane for 30 minutes to give a hydrocarbon (HC) fraction, then with benzene to give a "benzene resin" fraction. Most of the condensed ring hydrocarbons were found in the benzene resin fraction. The benzene elution was continued until disappearance of color from the eluting solvent. An "acid resin" fraction remaining on the silica gel was desorbed with alcohol benzene $(1: 1)$ to give an "alcohol-benzene" resin fraction.

Infrared spectra were obtained on carbon tetrachloride $\left(\mathrm{CCl}_{4}\right)$ solutions in $\mathrm{NaCl}$ cuvettes using a scanning Hilger spectrometer in the range from 1800 to $900 \mathrm{~cm}^{-1}$. Simultaneously the IR spectra were recorded on a punched tape and then treated on the digital computer.

\footnotetext{
'Manuscript was reviewed by Jean Whelan.
}

TABLE 1

List of Samples Examined

\begin{tabular}{|c|c|c|c|}
\hline No & Core & Section & $\begin{array}{l}\text { Sediment Depth } \\
(\mathrm{m})\end{array}$ \\
\hline \multicolumn{4}{|c|}{ Hole 379} \\
\hline $\begin{array}{l}1 \\
2 \\
3 \\
4 \\
5\end{array}$ & $\begin{array}{l}1 \\
5^{\mathrm{a}} \\
7 \\
8 \\
9\end{array}$ & $\begin{array}{l}\mathrm{CC} \\
3 \\
\mathrm{CC} \\
\mathrm{CC} \\
\mathrm{CC}\end{array}$ & $\begin{array}{c}0-7.0 \\
73.5-83.0 \\
121.0-130.5 \\
130.5-140.0 \\
149.5-159.0\end{array}$ \\
\hline
\end{tabular}

\begin{tabular}{|c|c|c|c|}
\hline \multicolumn{4}{|c|}{ Hole $379 \mathrm{~A}$} \\
\hline 6 & 21 & 1 & $187.5-197.0$ \\
\hline 7 & 25 & 4 & $225.5-235.0$ \\
\hline 8 & 27 & 4 & $244.5-254.0$ \\
\hline 9 & 29 & 4 & $263.5-273.0$ \\
\hline 10 & 31 & 6 & $282.5-292.0$ \\
\hline 11 & 34 & 3 & $311.0-320.5$ \\
\hline 12 & 34 & $\mathrm{CC}$ & $311.0-320.5$ \\
\hline 13 & $35^{\mathrm{a}}$ & 5 & $320.5-330.0$ \\
\hline 14 & 36 & 5 & $330.0-339.5$ \\
\hline 15 & 37 & $\mathrm{CC}$ & $339.5-349.0$ \\
\hline 16 & 43 & 3 & $387.0-396.5$ \\
\hline 17 & $47^{\mathrm{a}}$ & 0 & $425.0-434.5$ \\
\hline 18 & 51 & 0 & $463.0-472.5$ \\
\hline 19 & 54 & & 491.5-501.0 \\
\hline 20 & $57^{\mathrm{a}}$ & $\mathrm{CC}$ & $520.0-529.5$ \\
\hline 21 & 59 & 3 & $539.0-548.5$ \\
\hline 22 & 65 & 4 & $586.5-596.0$ \\
\hline 23 & $68^{\mathrm{a}}$ & 6 & $615.0-624.5$ \\
\hline
\end{tabular}

a Triplicate samples chosen for simulating.

UV-spectra were obtained on a scanning "Specord" instrument, "Carl Zeiss," Iena, DDR using a quartz cuvette ( $2 \mathrm{ml} ; 1 \mathrm{~cm}$ thick). The scanning range was 5400 to $16,000 \mathrm{~cm}^{-1}$.

Data on the composition of paraffin hydrocarbons in the paraffin-naphthene fractions were obtained by means of gas-liquid chromatography. The analyses were performed on a Pye gas chromatograph with the use of a 25 meter Apiezon L capillary column with temperature programming from $125^{\circ}$ to $300^{\circ} \mathrm{C}$.

\section{Results and Preliminary Discussion}

Organic matter content of the section is fairly constant and ranges from $0.40 \%$ to $1.43 \%$, except for Sample 29 in which it is $3.79 \%$ (Table 2). Carbonate content of the sediments varies from $2.74 \%$ to $15.28 \%$.

The physical properties of the bitumoid $\mathrm{A}_{\mathrm{chl}}$ and $\mathrm{A}_{\mathrm{alb}}$ extracts are different. The concentrate from the chloroform extract is light colored, solid, waxy; the solid residue from the alcohol-benzene extract is dark brown to black, resinous, solid. Both extracts are rich 
TABLE 2

Bituminological Characteristics of Organic Matter of Sediments

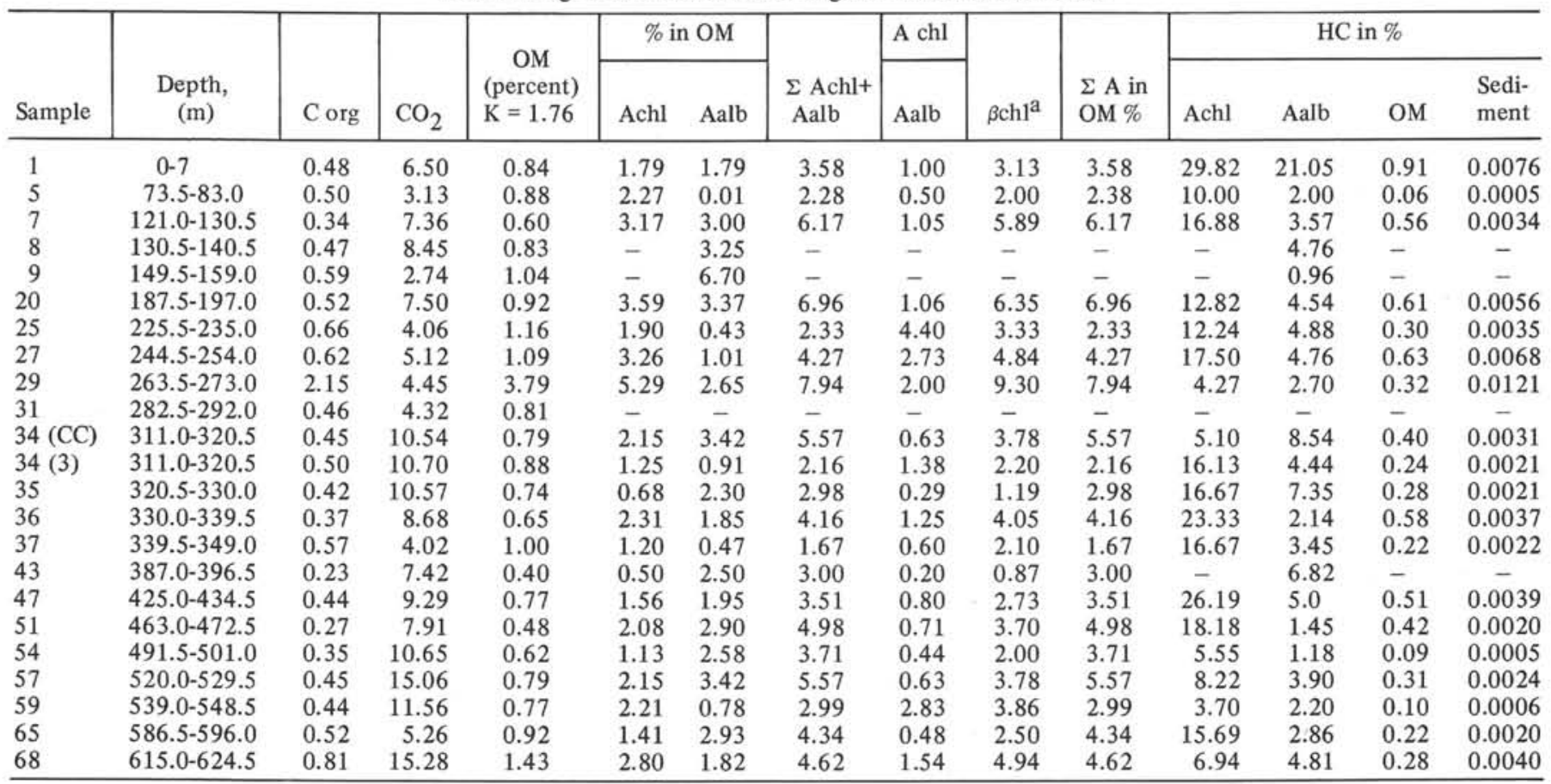

$\mathrm{a}_{\beta \mathrm{chl}}=\frac{\text { Achl (sediment) } 100}{\text { Corg. }}$

in elemental sulfur, and the alcohol-benzene extract contains a large amount of mineral salts.

Bitumoid "A" accounts for $1.67 \%$ to $7.94 \%$ of the organic carbon, the highest quantity being found in the samples with average organic carbon values (Figure 1). No relationship is apparent between the concentration of bitumoid "A" and the depth of the sample. The concentration of the bitumoid and its fractional composition depend to a high degree on the initial type of organic matter and its earlier transformations. Table 2 shows that $A_{\text {chl }}$ concentration is insignificant (from $0.5 \%$ to $5 \%$ of the organic matter) and bitumoid " $\mathrm{A}$ " is represented mainly by the alcohol-benzene extract of the "acid resin" components,

$$
\begin{aligned}
& \frac{A_{\text {chl }}}{A_{\text {alb }}}<1, \beta=\frac{A_{\text {chl }} \text { (sediment) } \times 100}{C_{\text {org }}}=0.8-6.0, \\
& \text { except for Sample 29, } \\
& \text { where } \beta_{\text {chl }}=9.30 .
\end{aligned}
$$

These data may be indicative, on one hand, of a low level transformation of organic matter, and, on the other hand, of organic matter that underwent a long oxidation in the water column.

The bitumoids $A_{\text {chl }}$ and $A_{\text {alb }}$ differ in fractional composition (Table 3 ). $A_{\text {chl }}$ is composed mainly of resins material ${ }^{2}$ (70\%-96\%) with an appreciable prevalence of acid alcohol-benzene resins over benzene resins ([benz.res.]/[alc/benz.res.] $=0.07-0.67$ ). Asphaltenes are absent in the group composition of

\footnotetext{
${ }^{2}$ Resins material=benzene resins + alc-benz resins where benzene resins and alcohol-benzene resins are materials eluted from the silica gel column with benzene and benzene-alcohol, respectively.
}

$A_{\text {chl }}$, except for Samples 27 and 59 (Figure 1). The latter samples were found to contain a rather high $\mathrm{A}_{\mathrm{chl}} / \mathrm{A}_{\mathrm{alb}}$ ratio (about 3), a high concentration of alcoholbenzene resins in $A_{\text {chl }}$ which is much in excess of benzene resins ([benz.res.]/[alc/benz.res.] $=0.12-0.08$ ). However, Samples 27 and 59 differ sharply from each other in $\mathrm{A}_{\text {alb }}$ composition. In the first sample the $\mathrm{A}_{\text {alb }}$ composition is represented by resin components (resins/asphalten $=4.13$ ), and in the second sample, by asphaltenes and a fraction insoluble in chloroform (resins/asphaltenes $=0.26$ ).

Based on the IR spectrometric data, benzene and alcohol-benzene resins of these samples differ considerably in the relationships between separate structural fragments (Table 4). As shown in Table 4, benzene and alcohol-benzene resins of both samples are rich in oxygen-containing groups in the form of acids, ethers and ketones, associated mainly with aliphatic structures. However, a relatively high content of carbonyl is noted in Sample 59 as related to aromatic rings (absorption band-1670 $\mathrm{cm}^{-1}$ ), and a high proportion of aromatic structures, especially in alcohol-benzene resins. According to the UV spectrometric data (Table 5), the aromatic structures of this sample are of a more condensed character than those of Sample 27 and are represented by anthracene and phenanthrene derivatives.

Benzene resins are the major source of the aromatic structures in Sample 27 represented mainly by benzene and naphthalene derivatives and to a lesser extent by anthracene and phenanthrene.

The above-mentioned similarity and differences in the composition of $\mathrm{A}_{\mathrm{chl}}$ and $\mathrm{A}_{\mathrm{alb}}$ of bitumoids and in the structure of benzene and alcohol-benzene resins of these samples may be attributed to either the similar 


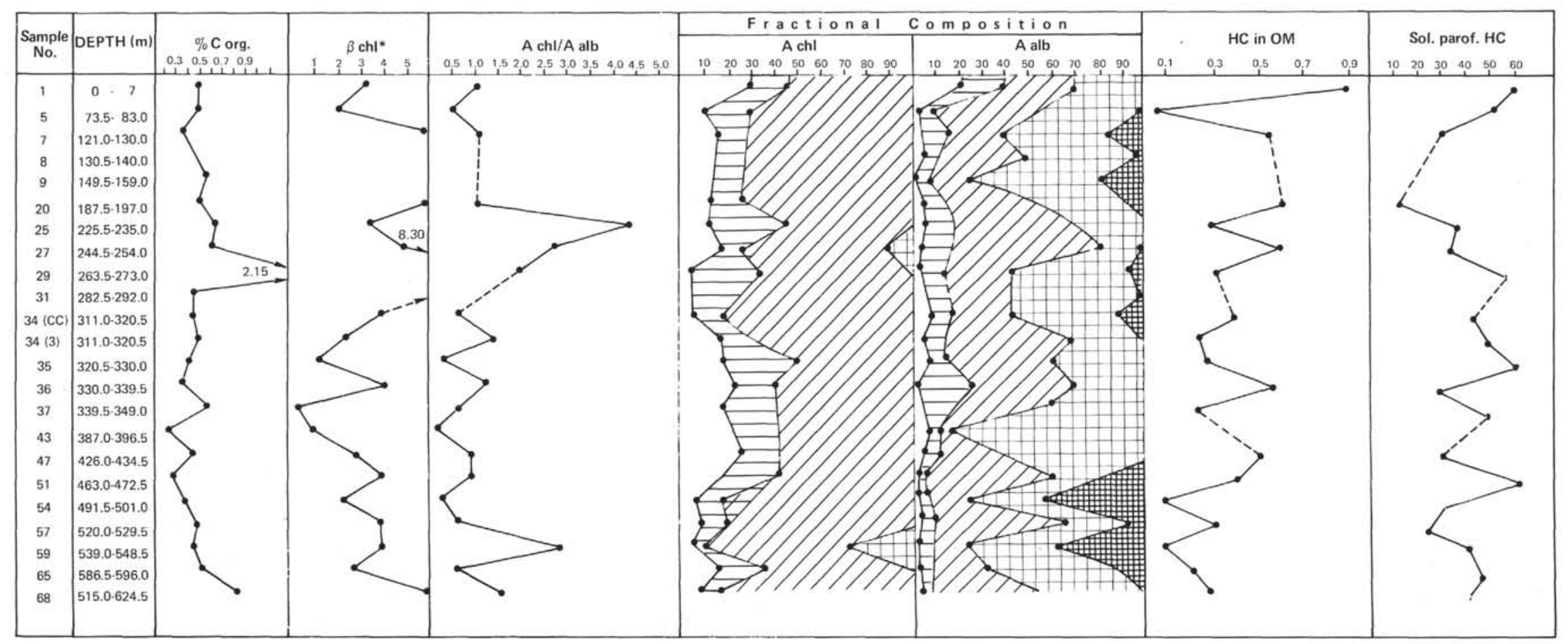

${ }_{\beta} \mathrm{chl}=\frac{(\text { A chl//g sediment) }) .100}{\text { C org }}$

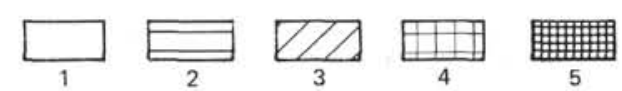

Figure 1. Distribution of $C_{\text {org }}$ and bitumoid components in the samples from the section. (1) hexane fraction; (2) benzene resins; (3) alcohol-benzene resins; (4) asphaltenes; (5) chlorofom insoluble fraction. 
TABLE 3

Fractional Composition of Bitumoid " $\mathrm{A}$ "

\begin{tabular}{|c|c|c|c|c|c|c|c|c|c|c|c|c|c|c|c|c|}
\hline \multirow[b]{3}{*}{ Sample } & \multicolumn{8}{|c|}{ Benzene Resins } & \multicolumn{8}{|c|}{ Alcohol-Benzene Resins } \\
\hline & \multicolumn{16}{|c|}{ Absorption $\left(\mathrm{cm}^{-1}\right)$} \\
\hline & 1740 & 1710 & 1670 & 1600 & 1470 & 1380 & 1115 & 1030 & $' 1740$ & 1710 & 1670 & 1600 & 1470 & 1380 & 1115 & 1030 \\
\hline 1 & 1.50 & 1.10 & 0.40 & 14.30 & 9.00 & 12.30 & 4.50 & 23.00 & 1.57 & 2.64 & 0.89 & 12.95 & 7.14 & 8.93 & 3.10 & 60.87 \\
\hline 5 & 0.90 & 1.26 & - & 8.60 & 6.70 & 6.30 & 8.30 & 9.20 & 1.43 & 1.79 & 0.46 & 8.21 & 6.71 & 10.27 & 5.00 & 60.44 \\
\hline 7 & 1.00 & 0.15 & - & 11.32 & 7.79 & 1.40 & 7.30 & 12.13 & 1.57 & 1.86 & 0.68 & 10.23 & 7.79 & 12.73 & 4.35 & 28.49 \\
\hline 20 & 0.51 & 1.20 & 1.21 & 15.80 & 4.30 & 10.10 & 4.80 & 22.60 & 0.89 & 1.39 & 0.36 & 4.69 & 4.57 & 7.67 & 1.85 & 9.64 \\
\hline 25 & 2.10 & 2.00 & 0.82 & 13.60 & 10.29 & 12.33 & 5.05 & 28.13 & 1.57 & 3.00 & 1.07 & 22.95 & 5.93 & 15.00 & 4.68 & 3.65 \\
\hline 27 & 5.10 & 8.60 & 5.17 & 76.97 & 30.21 & 47.47 & 15.73 & - & 2.43 & 3.64 & 0.89 & 14.92 & 9.86 & 9.40 & 3.00 & 8.27 \\
\hline 29 & 0.79 & 1.96 & 0.21 & 5.50 & 6.50 & 5.50 & 1.60 & 8.90 & 2.04 & 5.04 & 1.61 & 22.68 & 20.71 & 21.00 & 6.18 & 8.27 \\
\hline $34(\mathrm{CC})$ & 1.07 & 0.46 & 0.25 & 0.65 & 3.60 & 6.60 & 0.87 & 1.98 & 2.50 & 2.86 & 0.46 & 3.16 & 7.71 & 16.40 & 5.68 & 10.40 \\
\hline $34(3)$ & 0.43 & 0.36 & 0.25 & 4.70 & 2.76 & 2.90 & 1.05 & 7.07 & 1.68 & 2.53 & - & - & 7.93 & - & - & 6.69 \\
\hline 35 & 2.40 & 3.30 & 1.75 & 4.29 & 15.14 & 24.07 & 15.73 & 43.24 & 2.07 & 2.64 & 0.79 & 17.70 & 7.29 & 16.47 & 2.83 & 42.69 \\
\hline 36 & 4.40 & 2.60 & 1.39 & 33.77 & 17.86 & 4.47 & 13.55 & 59.80 & 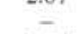 & - & 2.84 & 36.06 & 10.29 & 19.07 & 7.00 & 46.73 \\
\hline 37 & 0.53 & 0.50 & 0.64 & 16.07 & 5.28 & 12.33 & 5.45 & 31.25 & 1.94 & 2.75 & 0.79 & 16.19 & 9.64 & 14.40 & - & 35.75 \\
\hline 47 & 2.90 & 3.40 & 1.46 & 44.87 & 14.29 & 20.13 & 4.63 & 47.98 & 3.29 & 1.96 & 0.71 & 17.77 & 8.79 & 6.73 & 4.18 & 27.73 \\
\hline 51 & 1.90 & 1.30 & 0.36 & 14.39 & 4.57 & 6.47 & 2.38 & 12.40 & 2.23 & 4.04 & 0.71 & 11.08 & 7.71 & 10.47 & 2.93 & 7.69 \\
\hline 54 & 1.40 & 1.30 & 1.61 & 21.50 & 8.00 & 18.20 & 12.20 & 32.50 & 1.50 & 2.14 & 0.79 & 12.31 & 7.86 & 11.40 & 4.50 & - \\
\hline 57 & 2.76 & 5.01 & 1.25 & 56.62 & 18.93 & 28.30 & 7.00 & 6.00 & 1.00 & 1.36 & 0.29 & 3.58 & 4.07 & 5.67 & 1.28 & 5.04 \\
\hline 59 & 8.20 & 16.10 & 8.61 & 29.09 & 71.64 & 61.40 & 10.13 & 8.76 & 11.43 & 23.57 & 4.46 & 51.04 & 58.57 & 53.33 & 20.25 & - \\
\hline 65 & 2.70 & 3.57 & 1.68 & 35.52 & 13.00 & 19.80 & 10.50 & $\begin{array}{r}04.40 \\
\end{array}$ & 0.18 & 3.00 & 0.14 & - & 9.21 & - & 8.03 & 36.53 \\
\hline 68 & 1.25 & 1.60 & 1.68 & 20.91 & 8.43 & - & 6.00 & 22.40 & 0.75 & 1.18 & 0.36 & 6.36 & 3.57 & 5.20 & 0.88 & 4.91 \\
\hline
\end{tabular}

TABLE 4

Molar Relationships of Functional Groups in Chromatographic Fractions of Bitumoid $\mathrm{A}_{\text {chl }}$

\begin{tabular}{|c|c|c|c|c|c|c|c|c|c|c|c|c|c|c|c|}
\hline \multirow[b]{3}{*}{ Sample } & \multicolumn{4}{|c|}{ A chl, $\%$} & \multirow[b]{3}{*}{$\Sigma$ resins } & \multirow[b]{3}{*}{$\frac{\text { Benz. res. }}{\text { A.-b. res. }}$} & \multicolumn{5}{|c|}{ A alb, 范 } & \multirow[b]{3}{*}{$\Sigma$ resins } & \multirow[b]{3}{*}{$\frac{\text { Benz.z. }}{\text { A.-b. res. }}$} & \multirow[b]{3}{*}{$\begin{array}{c}\Sigma \text { asph.+ } \\
\text { unsol. }\end{array}$} & \multirow{3}{*}{$\begin{array}{l}\Sigma \text { resins } \\
\sum \text { asph. } \\
+ \text { unsol. }\end{array}$} \\
\hline & & & & & & & & & & & Fraction & & & & \\
\hline & $\mathrm{HC}$ & $\begin{array}{l}\text { Benz. } \\
\text { resins }\end{array}$ & $\begin{array}{l}\text { Alc.-benz. } \\
\text { resins }\end{array}$ & Asphal. & & & $\mathrm{HC}$ & $\begin{array}{l}\text { Benz. } \\
\text { resins }\end{array}$ & $\begin{array}{c}\text { Alc.-benz. } \\
\text { resins }\end{array}$ & Asph. & $\begin{array}{l}\text { unsol. in } \\
\text { Chlorof. }\end{array}$ & & & & \\
\hline 1 & 29.82 & 15.79 & 54.39 & - & 70.18 & 0.29 & 21.05 & 19.30 & 31.58 & 21.05 & 7.02 & 50.88 & 0.61 & 27.07 & 1.88 \\
\hline 5 & 10.00 & 20.00 & 70.00 & - & 90.00 & 0.28 & 2.00 & 7.00 & 45.00 & 46.00 & - & 52.00 & 0.16 & 46.00 & 0.88 \\
\hline 7 & 16.88 & 11.69 & 71.43 & - & 83.12 & 0.16 & 3.57 & 13.10 & 21.12 & 47.62 & 14.29 & 34.22 & 0.62 & 61.91 & 0.55 \\
\hline 8 & - & - & - & - & - & - & 4.76 & 6.35 & 38.10 & 50.79 & - & 44.45 & 0.17 & 50.79 & 0.86 \\
\hline 9 & - & - & - & - & - & - & 0.96 & 5.74 & 17.18 & 48.80 & 17.22 & 22.92 & 0.33 & 66.02 & 0.35 \\
\hline 20 & 12.82 & 12.82 & 74.36 & - & 87.18 & 0.17 & 4.57 & 10.61 & 43.94 & 37.88 & 3.03 & 54.55 & 0.24 & 40.91 & 1.33 \\
\hline 25 & 12.24 & 30.61 & 57.15 & - & 87.76 & 0.54 & 4.88 & 14.63 & 53.66 & 26.83 & - & 68.29 & 0.27 & 26,83 & 2.55 \\
\hline 27 & 17.50 & 17.50 & 63.50 & 12.50 & 71.00 & 0.12 & 4.76 & 11.90 & 64.77 & 18.57 & - & 76.67 & 0.18 & 18.57 & 4.13 \\
\hline 29 & 4.27 & 29.89 & 65.84 & - & 95.73 & 0.45 & 2.70 & 10.81 & 28.38 & 52.03 & 6.08 & 39.19 & 0.38 & 58.11 & 0.67 \\
\hline 31 & - & - & - & - & - & - & - & - & - & - & - & - & - & - & - \\
\hline $34(\mathrm{CC})$ & 5.10 & 11.84 & 83.06 & - & 94.90 & 0.14 & 8.54 & 8.54 & 26.82 & 45.12 & 10.98 & 35.36 & 0.32 & 56.10 & 0.63 \\
\hline 34 (3) & 16.13 & 12.90 & 70.97 & - & 83.87 & 0.18 & 4.44 & 8.88 & 55.57 & 31.11 & - & 64.45 & 0.16 & 31.11 & 2.07 \\
\hline 35 & 16.67 & 33.33 & 50.00 & - & 83.33 & 0.67 & 7.35 & 7.35 & 44.12 & 41.18 & - & 51.47 & 0.17 & 41.18 & 1.25 \\
\hline 36 & 23.33 & 16.67 & 60.00 & - & 76.67 & 0.28 & 2.14 & 25.12 & 42.38 & 30.36 & - & 67.50 & 0.59 & 30.36 & 2.22 \\
\hline 37 & 16.67 & 25.00 & 58.33 & - & 83.33 & 0.43 & 3.45 & 12.07 & 40.41 & 44.07 & - & 52.48 & 0.30 & 44.07 & 1.19 \\
\hline 43 & - & - & - & - & - & - & 6.22 & 4.55 & 2.27 & 86.36 & - & 6.82 & - & 86.36 & - \\
\hline 47 & 26.19 & 16.67 & 57.14 & - & 73.81 & 0.29 & 5.00 & 6.67 & 30.00 & 58.33 & $\overline{0}$ & 36.67 & 0.22 & 58.33 & 0.63 \\
\hline 51 & 18.18 & 22.73 & 59.09 & - & 81.82 & 0.38 & 1.45 & 1.45 & 57.97 & 21.74 & 17.39 & 59.42 & 0.03 & 39.13 & 1.52 \\
\hline 54 & 5.55 & 11.11 & 83.34 & - & 94.45 & 0.13 & 1.18 & 4.71 & 15.29 & 31.76 & 47.06 & 20.00 & 0.31 & 78.82 & 0.25 \\
\hline 57 & 8.22 & 10.96 & 80.82 & - & 91.78 & 0.14 & 3.90 & 4.68 & 57.04 & 34.38 & - & 61.72 & 0.08 & 34.38 & 1.80 \\
\hline 59 & 3.70 & 64.94 & 62.96 & 28.40 & 67.90 & 0.08 & 2.20 & 5.55 & 14.47 & 38.89 & 38.89 & 20.02 & 0.38 & 77.78 & 0.26 \\
\hline 65 & 15.69 & 23.53 & 60.78 & - & 84.31 & 0.39 & 2.86 & 4.76 & 22.85 & 58.10 & 11.43 & 27.61 & 0.21 & 69.53 & 0.40 \\
\hline 68 & 6.94 & 6.25 & 86.81 & - & 93.06 & 0.07 & 4.81 & 2.88 & 51.93 & 40.38 & - & 54.81 & 0.06 & 40.38 & 1.36 \\
\hline
\end{tabular}

conditions of organic matter transformation, or to the differences in organic matter's initial composition.

These samples differ considerably from one another in the content of the "hydrocarbon" fraction or hexanecluant (Sample 27; 29\%, Sample 59; 6\%). However, the composition of these samples, according to the gas-liquid chromatography and mass spectrometry, is very similar (Tables 6, 7).

The paraffin-naphthene fraction was found to contain solid high-molecular weight paraffins with the number of carbon atoms in a molecule from $\mathrm{C}_{17}$ to $\mathrm{C}_{35}$ with clear-cut maxima in the regions of $\mathrm{C}_{27}, \mathrm{C}_{29}$, and $\mathrm{C}_{31}$, and with a noticeable predominance of the normal structure hydrocarbons (more than 95\%) over isoparaffins. The n-alkanes series is characterized by a predominance of n-alkanes with an odd number of carbon atoms in molecules; the odd/even ratio ranges from 1.08 to 2.35 (Table 6). All the samples were found to contain pristane and phytane; the ratio of pristane to phytane ranges from 0.30 to 0.93 .
Paraffin hydrocarbons comprise from $25 \%$ to $59 \%$ in the paraffin-naphthene fraction (Table 7), i.e., amounts of paraffin hydrocarbons vary widely and, as seen from Figure 1, do not show any dependence on sediment depth. The surface sediments are characterized by the highest content of paraffin hydrocarbons (Sample 1, depth 0-7 m).

Among cyclic hydrocarbons, 1-6-ring structures with a predominance of mono-, bi-, and tricyclic ones were distinguished.

Such a composition of the "hydrocarbon" fraction is evidently determined by the facial and ecological peculiarities of the sedimentation and early diagenesis stages.

Interesting data were obtained for Sample 47 (depth 425-434 m). Despite the low level of the transformation of organic matter $\left(A_{c h l} / A_{\text {alb }}=0.97\right)$, the sum of "hydrocarbons" per bitumoid " $A$ " is rather large (31\%, $26 \%$ of them in $A_{c h 1}$ ). The composition of $A_{c h 1}$ was found to lack asphaltenes, and $A_{\text {alb }}$ contains no 
TABLE 5

Relative Content of Aromatic Structures in Resins of Bitumoid "A" Based on UV-Spectroscopic Data (internal standard)

\begin{tabular}{|c|c|c|c|c|c|c|c|c|c|c|}
\hline \multicolumn{6}{|c|}{ Benzene Resins } & \multicolumn{5}{|c|}{ Alcohol-Benzene Resins } \\
\hline Sample & Sulfides & Thiophenes & Naphthalenes & Benzenes & Antracenes & Sulfides & Thiophenes & Naphthalenes & Benzenes & Anthracenes \\
\hline 1 & 4.2 & 4.3 & 3.8 & 3.9 & - & & & & & \\
\hline 5 & 3.6 & 2.9 & - & 2.1 & - & 3.3 & 4.4 & 3.8 & 2.7 & 3.8 \\
\hline 7 & 13.3 & - & 14.8 & 11.1 & & & & & & \\
\hline 8 & & & & & & 9.7 & 9.4 & 7.8 & 5.4 & 7.5 \\
\hline 9 & & & & & & 6.8 & - & 5.6 & 3.6 & 5.4 \\
\hline 20 & 7.0 & 4.4 & 7.6 & 5.4 & - & & & & & \\
\hline 25 & 3.6 & 2.6 & - & - & 2.0 & & & & & \\
\hline 27 & 21.0 & 28.6 & 30.8 & - & 32.6 & & & & & \\
\hline 29 & 1.0 & 1.0 & 1.0 & - & 1.0 & & & & & \\
\hline $34(\mathrm{CC})$ & 4.1 & 5.7 & - & 2.9 & 8.0 & 5.3 & 6.7 & 5.9 & 4.4 & 6.2 \\
\hline $34(3)$ & 3.1 & 4.1 & 4.2 & - & 4.0 & & & & & \\
\hline 35 & 8.1 & 11.9 & 11.4 & - & - & 14.3 & - & 12.2 & - & - \\
\hline 36 & 15.8 & 18.6 & 16.7 & 8.6 & 12.0 & & & & & \\
\hline 37 & 2.8 & - & 2.7 & 1.3 & 3.8 & 11.0 & - & 10.9 & 6.7 & 9.4 \\
\hline 47 & 6.5 & 7.6 & 6.6 & - & 15.2 & 1.5 & - & 1.9 & 1.3 & - \\
\hline 51 & 6.6 & 7.1 & - & - & 5.6 & & & & & \\
\hline 54 & 1.3 & 1.9 & 1.7 & 1.0 & 1.4 & 6.4 & 8.6 & 7.5 & 6.8 & 9.5 \\
\hline 57 & 7.0 & - & - & 4.3 & 7.0 & 2.0 & 8.7 & 7.4 & 6.3 & - \\
\hline 59 & 4.7 & 5.7 & - & 6.1 & - & 23.6 & 30.0 & 27.7 & 18.6 & 26.0 \\
\hline 65 & 5.7 & 6.1 & - & 3.0 & 4.2 & 5.8 & 7.1 & - & - & 4.0 \\
\hline 68 & 7.6 & 8.6 & 6.2 & 4.4 & 6.2 & 1.6 & - & 1.4 & - & - \\
\hline
\end{tabular}

chloroform insoluble fraction. The same sample was found to have a relatively high content of heavy hydrocarbon gases $\left(C_{2}+C_{3}\right.$, Table 8) of which the saturated ones are much in excess of the unsaturated ones (sat./unsat. $=55.6$ ).

The paraffin-naphthene fraction has a relatively high percentage of paraffin hydrocarbons $(58.4 \%)$ among which n-alkanes with the odd number of carbon atoms in a molecule are much in excess of n-alkanes with the even number of carbon atoms (odd/even $=2.47$ ), and a low percentage of naphthenes (38.9\%) with the predominance of mono- and tricyclic structures.

According to the infrared spectra, benzene and alcohol-benzene resins of Sample 47 contain small amounts of oxygen-containing groups which are associated, as a rule, with the aliphatic structures. Benzene resins have the major content of the aromatic structures and the latter, based on the UV spectroscopic data, are represented primarily by benzene and naphthalene derivatives. Polynuclear aromatic structures have not been detected.

The organic matter in Sample 47 is likely to be rich in the lipid components. Its transformation evidently proceeded in the reducing environment.

Sample 1 taken from a depth of $0-7 \mathrm{~m}$, i.e., from the intensive fermentation-microbial activity zone, stands noticeably apart based on the bituminological characteristics. A comparatively high percentage of $\beta_{\mathrm{chl}}$ is noted (3.13) (Table 2) together with an organic matter content of $0.84 \%$. The bitumoid " $\mathrm{A}$ ", as in the rest of the samples, is represented mainly by resins in which alcohol-benzene resins dominate over benzene ones. Asphaltenes are absent in $\mathrm{A}_{\mathrm{chl}}$. In $\mathrm{A}_{\text {alb }}$ they comprise $21.05 \%$. However, Sample 1 differs considerably from the others in the composition and structure of some of the fractions. The greatest amount of "hydrocarbons", comprising $0.91 \%$ of the organic matter, has been found in this sediment. Among the "hydrocarbons," n-alkanes are predominant $(59.2 \%)$ of which low carbon number $\left(\mathrm{C}_{17}-\mathrm{C}_{24}\right)$ ones amount to over 50\% (Tables 6 and 7). Paraffin hydrocarbons contain almost equal amounts $\left(\left[\mathrm{i}_{19}\right] /\left[\mathrm{i} \mathrm{C}_{20}\right]=0.93\right)$ of pristane and phytane. The ratio of odd to even nalkanes is 1.08 .

The IR spectra of the samples show no sharp difference between the benzene and the alcoholbenzene resin fractions: oxygen-containing groups play a significant part in the composition of both fractions. These groups are represented mainly by acids, ethers, and ketones associated with the aliphatic structures. Carbonyl associated with the aromatic structures are contained in a greater proportion in benzene resins than in alcohol-benzene resins.

A rather high content of the naphthene-aromatic and aromatic structures is noted in benzene and alcoholbenzene resins (Table 4). The aromatic fragments, based on the UV spectroscopic data, are represented mainly by benzene and naphthalene derivatives and, to a much lesser extent and not in all the samples, by anthracene and phenanthrene derivatives. More condensed aromatic structures were not found.

The established value of the odd coefficient close to zero (as in oil), as well as the high content of paraffins in the paraffin-naphthene fraction, can serve as evidence of the biochemical process of the formation of paraffin hydrocarbons at the sedimento-genesis and early diagenesis stages.

\section{SIMULATION OF THE TRANSFORMATION OF DISPERSED ORGANIC MATTER}

The reproduction of the natural geochemical processes, especially of oil and gas formation, in the laboratory entails certain difficulties. The kinetics of these processes are such that to reproduce them to the full extent in short experimental times is impossible. For instance, an intensive temperature effect may 
밍

包|్ㅠ

लூ

गे 1 i $1=\underset{0}{\infty}$

$= \pm 1=1 \frac{1}{0} \pm \pm=$

m్

+๐

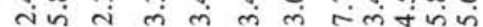

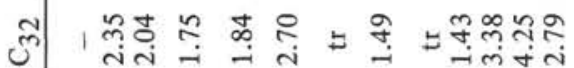

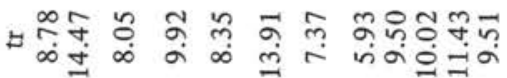

이

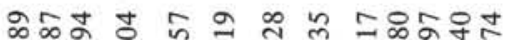
फंते

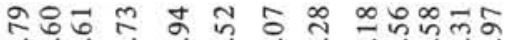

$$
\text { ง }
$$

$\stackrel{\sim}{\sim}$

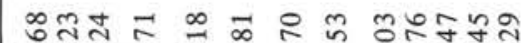

ल๗ळ బ

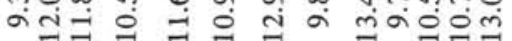

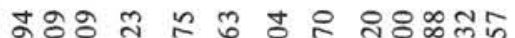

लेंด्र

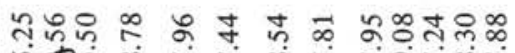

víb $\infty$

茫

ஜூ̊

vi

กิ

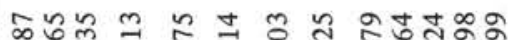

กี่

ஓ이 유

in

$\bar{v}$

ำ

กู๊ๆ

ㅇำ

लिं में के में

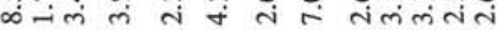

v

ㅇำำ

$\stackrel{\infty}{\sim}$

u

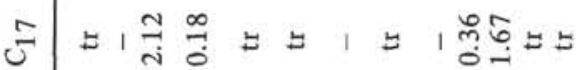

్ㅠ ঞँ

2

는

羿

भे

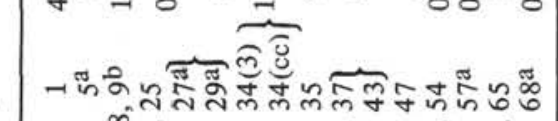

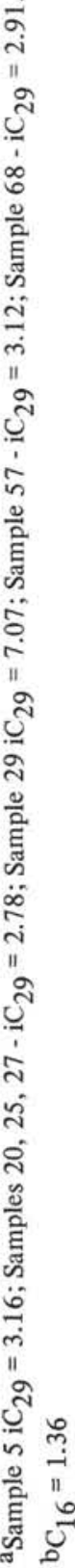

change the trend of the consecutive processes. Therefore, all the conditions of the experiment should be limited by certain parameters. Evaluation of the results depends to a considerable extent on these limits.

\section{Experimental Procedure}

The samples for the experiment were selected aboard ship from the core with the aid of a special core receiver. A sample cut from the core was placed in a thin-walled cylindrical capsule of Teflon (fluorocarbon plastic) and stoppered. Using the simulation device (Figure 2), the studies were carried out under three sets of conditions. The sinking of the samples into the bottom was simulated to the depths $\mathrm{H}$ of $3.5 \mathrm{~km}, 5 \mathrm{~km}$, $6.5 \mathrm{~km}$. Temperatures (t) and pressures (p) for these conditions are given in Table 9 . The experiments were made in a pressure chamber (1) in which temperature and pressure are controlled and stabilized with the aid of an external heater, (2) fitted with an electronic control and a hydropress, (3) with a drive providing the compression stress $\mathbf{S}$.

The sampling system for liquid and gas provides the accumulation of these components during the whole experimental period and their periodic sampling for the studies. The system incorporates a calibrated trap for liquid (4), a four-position vacuum valve (5), a gas accumulator (6) filled with mercury, and a changeable cap (7) for gas sampling.

A sample (8) in the capsule (9) without covers is placed into a plastic chamber (10) and at the ends is separated from the latter by a quartz sand layer (11). In the lower sand layer there is a discharge pipe (12)

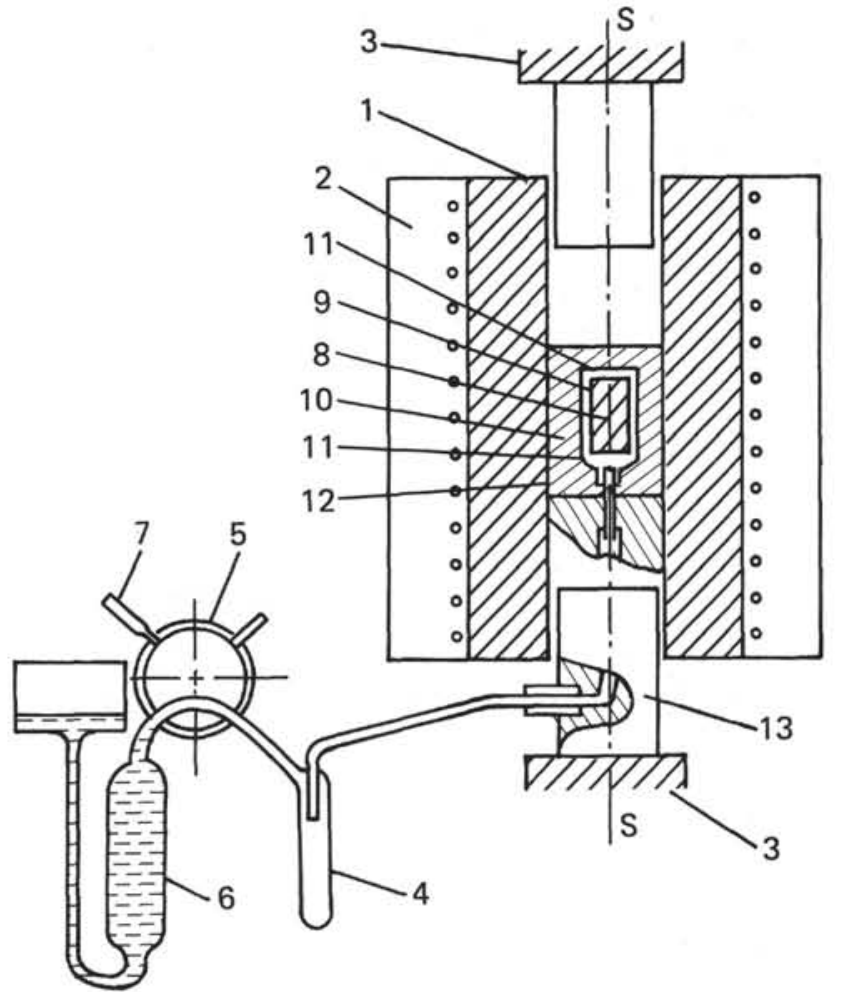

Figure 2. Scheme of the simulation device. 
TABLE 7

Composition of Paraffin-Naphthene Fraction of Hydrocarbons (based on mass spectrometry data, ratio in \%)

\begin{tabular}{|c|c|c|c|c|c|c|c|c|}
\hline \multirow[b]{2}{*}{ Sample } & \multirow{2}{*}{$\begin{array}{l}\text { Paraffin } \\
\text { Hydro- } \\
\text { carbons }\end{array}$} & \multicolumn{6}{|c|}{ Naphthene Hydrocarbons } & \multirow[t]{2}{*}{ Alkylbenzenes } \\
\hline & & one-ring & two-ring & three-ring & four-ring & five-ring & six-ring & \\
\hline 1 & 59.2 & 10.2 & 7.4 & 11.3 & 4.0 & 3.1 & 3.3 & 1.5 \\
\hline 5 & 52.8 & 14.0 & 5.3 & 12.1 & 5.3 & 3.2 & 2.2 & 5.1 \\
\hline 7 & 32.7 & 23.7 & 7.3 & 22.9 & 3.1 & 3.3 & 2.3 & 4.5 \\
\hline 20 & 12.4 & 49.2 & 4.3 & 22.4 & 3.1 & 3.4 & 1.2 & 4.0 \\
\hline 25 & 37.7 & 14.6 & 12.4 & 17.6 & 6.2 & 4.7 & 2.0 & 4.8 \\
\hline 27 & 36.6 & 25.4 & 8.1 & 20.3 & 4.4 & 1.2 & 1.0 & 2.9 \\
\hline 29 & 54.7 & 5.9 & 8.5 & 18.4 & 3.3 & 1.5 & 1.2 & 6.5 \\
\hline $34(\mathrm{cc})$ & 42.0 & 11.65 & 13.1 & 20.9 & 3.8 & 2.7 & 1.6 & 4.4 \\
\hline $34(3)$ & 45.8 & 8.3 & 25.1 & 6.5 & 5.2 & 5.5 & 2.4 & 1.2 \\
\hline 35 & 49.0 & 19.6 & 5.4 & 14.2 & 3.5 & 3.1 & 1.6 & 3.6 \\
\hline 36 & 26.5 & 20.4 & 9.8 & 15.6 & 4.2 & 3.8 & 1.9 & 11.8 \\
\hline 37 & 50.1 & 14.1 & 6.0 & 16.9 & 3.8 & 3.8 & 1.4 & 3.9 \\
\hline 47 & 28.4 & 16.2 & 5.1 & 22.3 & 4.9 & 3.5 & 3.8 & 15.8 \\
\hline 51 & 48.3 & 20.2 & 5.3 & 1.3 & 4.2 & 3.9 & 1.6 & 5.2 \\
\hline 54 & 28.9 & 15.5 & 11.3 & 24.7 & 9.4 & 4.2 & 2.6 & 3.4 \\
\hline 57 & 25.3 & 33.8 & 3.8 & 11.3 & 10.3 & 6.4 & 5.5 & 3.6 \\
\hline 59 & 40.7 & 6.4 & 14.2 & 20.3 & 11.0 & 4.4 & 2.0 & 1.0 \\
\hline 65 & 42.8 & 13.6 & 11.2 & 18.1 & 4.2 & 3.1 & 1.9 & 5.3 \\
\hline 68 & 36.9 & 8.3 & 8.0 & 15.2 & 12.4 & 6.5 & 5.3 & 7.4 \\
\hline
\end{tabular}

TABLE 8

Composition of Gases Liberated During the Experiment

\begin{tabular}{|c|c|c|c|c|c|c|c|c|c|c|c|}
\hline \multirow[b]{2}{*}{ Sample } & \multirow[b]{2}{*}{$\begin{array}{c}\text { Condi- } \\
\text { tions }\end{array}$} & \multirow[b]{2}{*}{$\begin{array}{l}\mathrm{CO}_{2} \mathrm{~cm} 3 / \mathrm{kg} \\
\text { of sediment }\end{array}$} & \multicolumn{8}{|c|}{ Hydrocarbonic Gases, $\left(\mathrm{cm} 3 / \mathrm{kg}\right.$ of sediment $\times 10^{-4}$} & \multirow{2}{*}{$\frac{\Sigma \text { satur. }}{\Sigma \text { unsatur. }}$} \\
\hline & & & $\mathrm{CH}_{4}$ & $\mathrm{C}_{2} \mathrm{H}_{6}$ & $\mathrm{C}_{2} \mathrm{H}_{4}$ & $\mathrm{C}_{3} \mathrm{H}_{8}$ & $\mathrm{C}_{3} \mathrm{H}_{6}$ & heavy $\mathrm{HC}$ & satur. & unsat. & \\
\hline 5 & before ${ }^{a}$ & 3.74 & 51.3 & - & - & - & - & - & - & - & - \\
\hline 5 & 1 & 17.40 & 2885.9 & 15.58 & 12.88 & 2.20 & 10.91 & 41.57 & 17.78 & 23.79 & 0.75 \\
\hline 5 & III & 298.59 & 19752.3 & 145.05 & 205.08 & 58.50 & 159.40 & 568.03 & 263.55 & 364.48 & 0.56 \\
\hline 35 & before ${ }^{a}$ & 40.90 & 2083.5 & 12.65 & 366.90 & $\operatorname{tr}$ & 29.30 & 408.85 & 12.65 & 396.20 & 0.03 \\
\hline 35 & II & 167.82 & 5016.1 & 34.52 & 310.40 & tr & 20.73 & 365.65 & 34.52 & 331.13 & 0.10 \\
\hline 35 & III & 733.75 & 14251.8 & 187.50 & 669.56 & 34.70 & 45.18 & 936.88 & 222.20 & 714.74 & 0.31 \\
\hline 47 & before ${ }^{a}$ & 11.59 & 423.9 & 72.90 & 3.90 & 705.60 & 10.11 & 792.50 & 778.50 & 14.00 & 55.60 \\
\hline 47 & II & 47.07 & 1360.3 & 42.16 & 7.30 & 306.80 & tr & 356.26 & 348.96 & 7.30 & 47.80 \\
\hline 47 & III & 20.80 & 1445.1 & 87.07 & 221.02 & 321.10 & $\operatorname{tr}$ & 629.19 & 408.17 & 221.02 & 1.85 \\
\hline 57 & before $^{a}$ & 0.92 & 228.8 & - & - & - & - & - & - & - & - \\
\hline 57 & 1 & 23.62 & 624.4 & 3.24 & 13.10 & $\mathrm{tr}$ & & 26.34 & 3.24 & 13.10 & 0.24 \\
\hline 57 & III & 302.05 & 2501.3 & 20.68 & 45.10 & tr & & 65.78 & 20.68 & 45.10 & 0.46 \\
\hline 68 & before ${ }^{a}$ & 3.04 & 199.5 & - & - & - & - & - & - & - & - \\
\hline 68 & II & 178.47 & 1957.2 & 16.50 & 23.30 & 4.85 & $\operatorname{tr}$ & 44.65 & 21.35 & 23.30 & 0.92 \\
\hline 68 & III & 352.98 & 4804.1 & 56.50 & 60.73 & 47.74 & $\operatorname{tr}$ & 164.97 & 104.24 & 60.73 & 1.72 \\
\hline
\end{tabular}

a Gas composition determined immediately after the attainment of the device of the predetermined thermobaric conditions (3-4 hours after the commencement of the experiment) is arbitrarily taken as pre-experimental. It is assumed that during this time mainly the desorption processes have been completed.

having an output through the plunger channel into the sampling system.

The experimental methods allow for a relatively fast (2-2.5 hours) attainment of the chamber with the sample to the predetermined thermobaric conditions and an exposure of the sample to these conditions during 76 hours. The connecting branches to the plunger and the trap for liquid are prefilled with helium. However, about $1.3 \mathrm{ml}$ of the air which was not removable from the sand and from the chamber remained in the system. The liquid liberated during the experiment accumulates in the trap, and gas after the displacement of mercury fills up the accumulator. Gas and liquid volumes are continuously recorded. The first gas sampling for the chromatographic analysis is made
TABLE 9

Conditions of Simulation Experiments

\begin{tabular}{cccc}
\hline \multirow{2}{*}{ Conditions } & $\mathrm{H}(\mathrm{km})$ & $\mathrm{t}\left({ }^{\circ} \mathrm{C}\right)$ & $\mathrm{P}\left(\mathrm{kg} / \mathrm{cm}^{2}\right)$ \\
\hline I & 3.5 & 105 & 770 \\
II & 5 & 154 & 1100 \\
III & 6.5 & 216 & 1430 \\
\hline
\end{tabular}

3.5-4 hours after the commencement of the experiment, the second one 50 hours, and the third one 77 hours after it. The total duration of the experiment is 78 hours.

On the completion of the experiment, the fluorine plastic chamber is cut and the sample is taken out of it 
for the analysis. Figure 3 shows the cut chamber and the general view of the sample and Figure 4 shows the sample in section.

\section{Chromatographic Studies of Gases Liberated During the Experiment}

The volumes of gas and liquid liberated in the experiment are presented in Table 10.

The analyses of $\mathrm{O}_{2}, \mathrm{~N}_{2}$, and $\mathrm{CO}_{2}$ were made on two experimental models of the HL-14 gas chromatograph with a thermal conductivity detector. The analysis of hydrocarbon gases was accomplished on the Tsvet- 4 gas chromatograph with an ionization-flame detector. The separation of $\mathrm{CO}_{2}$ and hydrocarbon gases was performed on an analytical silica gel column.

The concentrations of individual gases are given in Table 8.

Since the air was not removed completely from the chamber, it was impossible to estimate $\mathrm{O}_{2}$ and $\mathrm{N}_{2}$ quantitatively, although the two gases were undoubtedly present.

As seen from Table 8, the gaseous phase of the initial samples (without $\mathrm{O}_{2}$ and $\mathrm{N}_{2}$ ) consists principally of

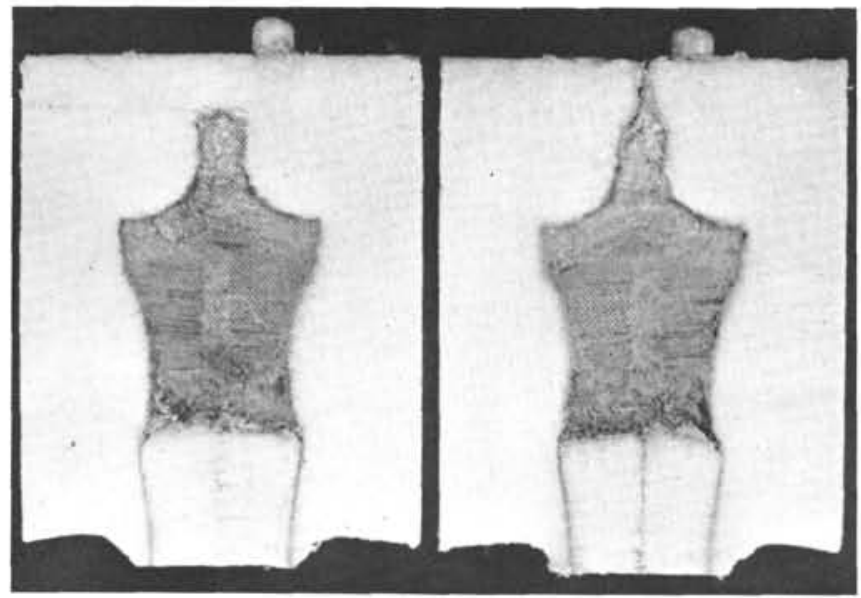

Figure 3. General view of the sample in the chamber after the experiment.

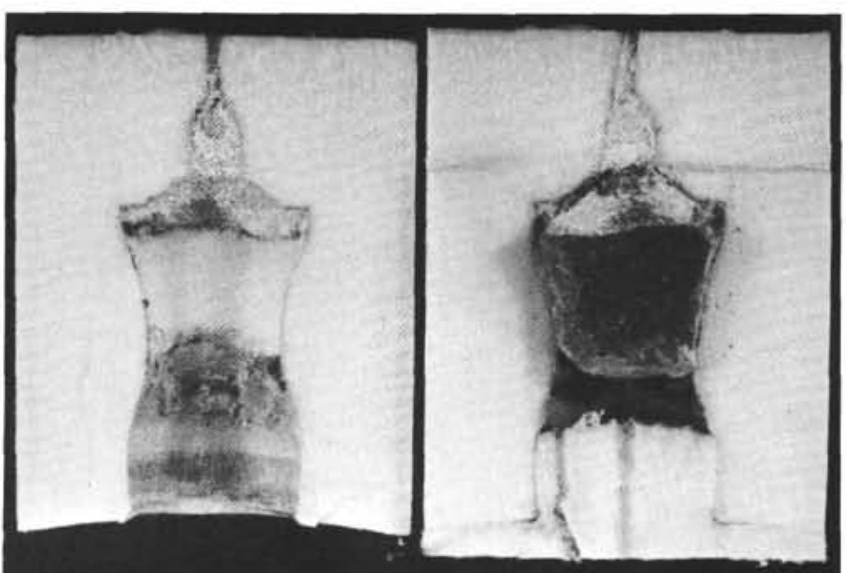

Figure 4. Sample in the chamber after the experiment in section.
$\mathrm{CO}_{2}(\sim 99 \%)$ and methane. Ethane, ethylene, propane, and propylene are found only in Samples 35 and 47. Heavier gases $\left(\mathrm{C}_{4}-\mathrm{C}_{5}\right)$ were discovered in no sample.

The experimental conditions, I, II, and especially III showed a sharp increase in amounts of $\mathrm{CO}_{2}$ and $\mathrm{CH}_{4}$, as shown in Figure 5. A simultaneous appearance of heavy hydrocarbon gases was noted. The concentration of the latter increased mainly at the expense of unsaturated hydrocarbons. In contrast, in the experiments with Sample 47, the content of propane decreased by nearly one-half relative to the initial amount.

Thus, the thermocatalytic transformation of organic matter is accompanied by an intensive $\mathrm{CO}_{2}$ liberation with a simultaneous formation of hydrocarbon gases. The concentrations of the gases and their relationships are determined to a large extent by the individual peculiarities of the initial organic matter.

\section{Results of the Bituminological Studies of the Samples}

The same series of the analyses by the same experimental methods were made for the samples before and after the simulation experiments.

Table 11 shows the data of the bituminological studies. From this table it is obvious that the total amount of bitumoids under experimental conditions I and II increases to a greater or lesser degree. Under the more severe conditions III, the content of bitumoids continues to grow, yet much more slowly. An increase of both $\mathrm{A}_{\mathrm{chl}}$ and $\mathrm{A}_{\mathrm{alb}}$ occurs.

It should be noted that the experiment reveals a trend in the reaction of bitumoids: the ratio $A_{\text {chl }} / A_{\text {alb }}$ increases considerably. In some of the samples the maximum increase of this ratio corresponds to relatively mild thermobaric conditions (Sample 35, condition II; Sample 68, condition II), in other samples- $(5,47,57)-$ to the severe experimental conditions (III). Similar changes are noticed for $\beta_{\text {chl }}$ (Figure 6).

The fractions of $A_{c h l}$ and $A_{\text {alb }}$ in the samples before the experiment, as indicated previously, are represented principally by the resins among which the alcoholbenzene resins are far in excess of the benzene ones. During the experiment the relationship between the fractions in both $A_{c h l}$ and $A_{\text {alb }}$ changes (Figure 7).

The content of the "hydrocarbon" fraction changes in both extracts, and these changes are of a dissimilar character in different samples (Table 12). However, in all the samples a distinct trend is apparent toward an increase of "hydrocarbons" in organic matter. A decrease in the content of "hydrocarbons" of $\mathrm{A}_{\mathrm{ch} 1}$ and $\mathrm{A}_{\mathrm{alb}}$ in some of the samples is probably accounted for by conversion of the solid $\mathrm{C}_{17}-\mathrm{C}_{34}$, hydrocarbons present initially, under the influence of temperature and pressure into lower molecular weight liquid and gaseous molecules which are lost during the extraction.

It is believed that a decrease in the amount of hydrocarbons, especially in $A_{\text {chl }}$ of Sample 47, is related to the presence of long-chain paraffin hydrocarbons in the "hydrocarbon" fraction of the initial sample.

A sharp increase of the content of the alcoholbenzene resins compared to the benzene ones in $\mathrm{A}_{\text {chl }}$ of 
TABLE 10

Volumes of Gases and Liquids Liberated During the Experiments (ml)

\begin{tabular}{|c|c|c|c|c|c|c|c|c|c|c|}
\hline \multirow[b]{2}{*}{ Sample } & \multirow[b]{2}{*}{$\begin{array}{l}\text { Condi- } \\
\text { tions }\end{array}$} & \multirow[b]{2}{*}{$\begin{array}{l}\text { Volume } \\
\text { of Upper } \\
\text { Sand }\end{array}$} & \multirow[b]{2}{*}{$\begin{array}{c}\text { Volume of Gas } \\
\text { Before } \\
\text { Experiment }\end{array}$} & \multicolumn{4}{|c|}{ Volume of Gas of } & \multirow[b]{2}{*}{$\begin{array}{l}\text { Volume of Gas } \\
\text { of Sample III } \\
\text { before } \\
\text { Sampling }\end{array}$} & \multirow[b]{2}{*}{$\begin{array}{l}\text { Total Volume } \\
\text { of Gas Genera- } \\
\text { ated }\end{array}$} & \multirow[b]{2}{*}{$\begin{array}{l}\text { Volume of } \\
\text { Liquid } \\
\text { Generated }\end{array}$} \\
\hline & & & & $\begin{array}{r}\text { Sam } \\
\text { before } \\
\text { Sampling }\end{array}$ & $\begin{array}{l}\text { le I } \\
\text { after } \\
\text { Sampling }\end{array}$ & $\begin{array}{l}\text { Sam } \\
\text { before } \\
\text { Sampling }\end{array}$ & $\begin{array}{l}\text { le II } \\
\text { after } \\
\text { Sampling }\end{array}$ & & & \\
\hline 5 & 1 & 1.06 & 22.11 & 26.70 & 18.55 & 20.7 & 16.65 & 16.65 & 6.54 & 5.40 \\
\hline 5 & III & 1.06 & 22.93 & 40.30 & 28.00 & 28.1 & 16.10 & 14.40 & 15.77 & 6.10 \\
\hline 35 & II & 2.15 & 15.05 & 22.70 & 13.20 & & & 14.70 & 9.15 & 3.50 \\
\hline 35 & III & 3.22 & 24.01 & 37.60 & 31.20 & 29.7 & 21.70 & 17.60 & 8.00 & 3.80 \\
\hline 47 & II & 1.06 & 14.51 & 20.00 & 12.30 & & & 12.50 & 5.70 & 4.60 \\
\hline 47 & III & 5.37 & 25.08 & 30.10 & 23.10 & & & 18.70 & 0.60 & 2.20 \\
\hline 57 & 1 & 1.06 & 29.00 & 26.17 & 17.56 & $\begin{array}{l}22.96 \\
\text { with add } \\
V=6.12\end{array}$ & 15.00 & 14.46 & 2.00 & 1.80 \\
\hline 57 & III & 0.53 & 33.00 & 40.84 & 29.28 & 28.82 & 16.82 & 17.30 & 8.60 & 4.10 \\
\hline 68 & II & 1.07 & 25.02 & 27.79 & 20.87 & 23.64 & 13.34 & 12.52 & 4.72 & 4.40 \\
\hline 68 & III & 0.54 & 31.92 & 40.53 & 31.33 & 31.23 & 21.99 & 19.84 & 6.36 & 4.10 \\
\hline
\end{tabular}
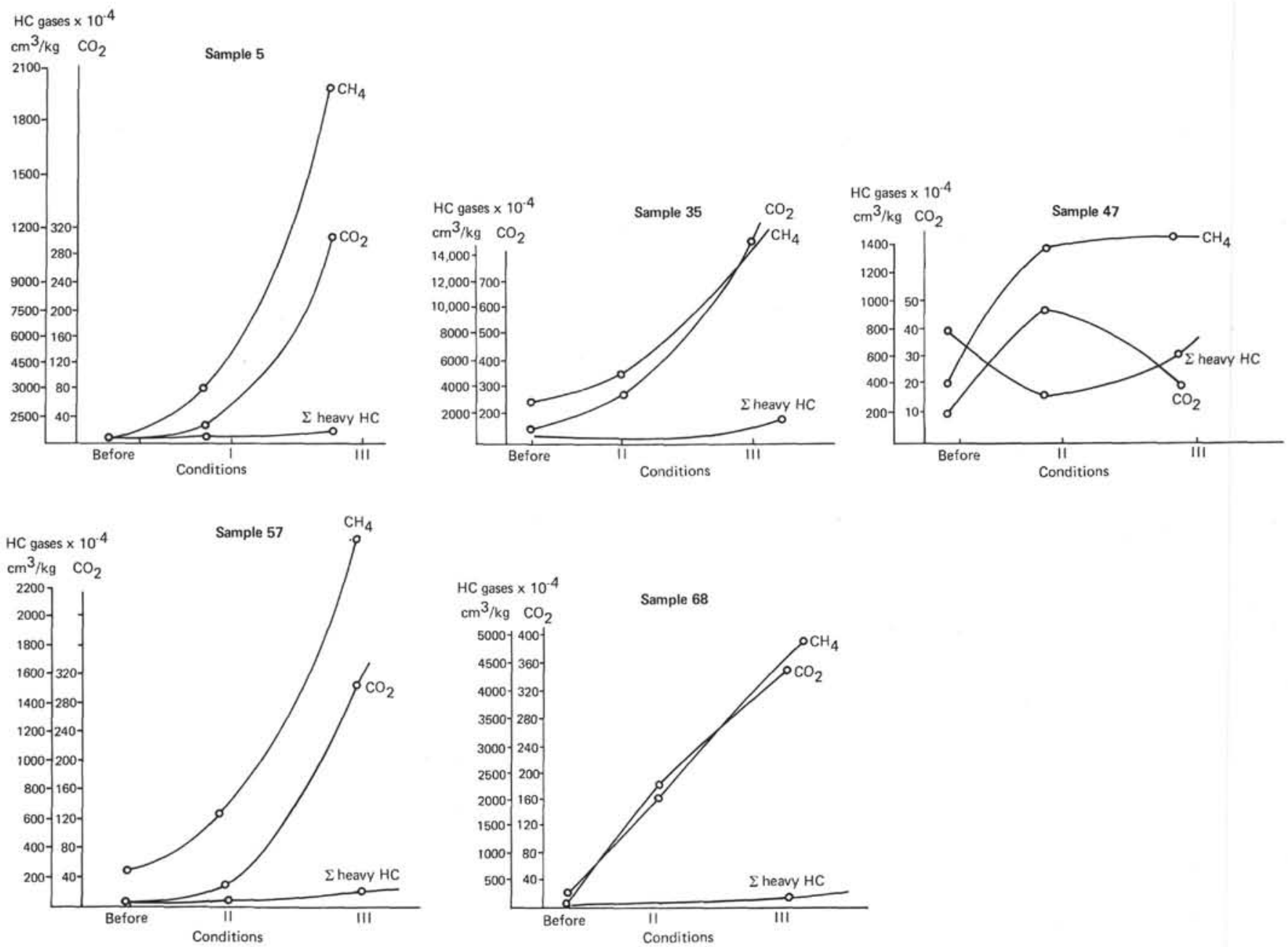

Figure 5. Distribution of gases as dependent on experimental conditions.

all the samples, except for Sample 68, can be attributed only to the presence of the atmospheric oxygen remains in the simulating chamber.

A relatively large amount of asphaltenes enters into the composition of $\mathrm{A}_{\mathrm{alb}}$ of the samples. Their content under the mild experimental conditions (I and II) decreases in Samples 5, 37, and 47 and increases in Samples 57 and 68.
A decrease in the abundance of asphaltenes is accompanied mainly by an increase of "hydrocarbons" and benzene resins. Such a distribution of the fractions under the experimental conditions is probably related to the fact that asphaltenes of the sediments under study are represented chiefly by the saturated (naphthenic and aliphatic) fragments and in much smaller quantities by the aromatic blocks. Under 
TABLE 11

Bituminological Characteristics of Organic Matter of Simulating Samples (\%)

\begin{tabular}{|c|c|c|c|c|c|c|c|c|c|c|c|c|c|}
\hline Sample & $\begin{array}{c}\text { Condi- } \\
\text { tions }\end{array}$ & Corg & $\begin{array}{l}\text { Org. } \\
\text { Matter }\end{array}$ & $\begin{array}{l}\text { Achl } \\
\text { in OM }\end{array}$ & $\begin{array}{l}\text { Aalb } \\
\text { in OM }\end{array}$ & $\frac{\text { Achl+ }}{\text { Aalb }}$ & $\begin{array}{l}\text { Achl } \\
\text { Aalb }\end{array}$ & $\begin{array}{c}\beta \\
\text { chl }\end{array}$ & $\begin{array}{c}\beta \\
\text { alb }\end{array}$ & $\begin{array}{l}\mathrm{HC}_{\text {chl }} \\
\text { in } \mathrm{OM}\end{array}$ & $\begin{array}{l}\mathrm{HC}_{\mathrm{alb}} \\
\text { in } \mathrm{OM}\end{array}$ & $\begin{array}{c}\mathrm{HC} \\
\text { in } \mathrm{OM}\end{array}$ & $\begin{array}{c}\mathrm{HC} \text { in } \\
\text { sedim.(\%) }\end{array}$ \\
\hline 5 & before & 0.50 & 0.88 & 0.11 & 2.27 & 2.38 & 0.50 & 2.00 & 4.00 & 0.01 & 0.05 & 0.06 & 0.0005 \\
\hline 5 & 1 & & & 5.45 & 6.82 & 12.27 & 0.80 & 9.60 & 12.00 & 0.40 & 0.12 & 0.52 & 0.0045 \\
\hline 5 & III & & & 8.64 & 7.84 & 16.58 & 1.10 & 15.20 & 13.80 & 0.42 & 0.08 & 0.50 & 0.0044 \\
\hline 35 & before & 0.42 & 0.74 & 0.68 & 2.30 & 2.98 & 0.29 & 1.19 & 4.05 & 0.11 & 0.17 & 0.28 & 0.0021 \\
\hline 35 & II & & & 9.46 & 3.24 & 12.70 & 2.92 & 16.67 & 5.71 & 0.79 & 0.23 & 1.02 & 0.0075 \\
\hline 35 & III & & & 8.38 & 4.19 & 12.57 & 2.00 & 14.76 & 7.38 & 0.51 & 0.28 & 0.79 & 0.0021 \\
\hline 47 & before & 0.44 & 0.77 & 1.56 & 1.96 & 3.51 & 0.80 & 2.73 & 3.41 & 0.41 & 0.10 & 0.51 & 0.0039 \\
\hline 47 & II & & & 1.56 & 2.85 & 4.41 & 0.55 & 2.73 & 5.00 & 0.17 & 0.23 & 0.40 & 0.0031 \\
\hline 47 & III & & & 1.25 & 3.38 & 4.63 & 1.31 & 7.73 & 5.91 & 0.14 & 0.14 & 0.28 & 0.0022 \\
\hline 57 & before & 0.45 & 0.79 & 2.15 & 3.42 & 5.57 & 0.63 & 3.78 & 6.00 & 0.18 & 0.13 & 0.31 & 0.0024 \\
\hline 57 & 1 & & & 2.26 & 4.68 & 6.94 & 0.49 & 4.00 & 8.22 & 0.36 & 0.30 & 0.66 & 0.0052 \\
\hline 57 & III & & & 2.28 & 2.15 & 4.43 & 1.06 & 4.00 & 3.78 & 0.26 & 0.21 & 0.47 & 0.0037 \\
\hline 68 & before & 0.81 & 1.43 & 2.80 & 1.82 & 4.62 & 1.54 & 4.94 & 3.21 & 0.19 & 0.09 & 0.28 & 0.0040 \\
\hline 68 & II & & & 2.59 & 1.40 & 3.99 & 1.85 & 4.56 & 2.47 & 0.37 & 1.40 & 0.37 & 0.0053 \\
\hline 68 & III & & & 2.80 & 4.90 & 7.70 & 0.57 & 4.94 & 8.64 & 0.34 & 4.90 & 0.34 & 0.0049 \\
\hline
\end{tabular}

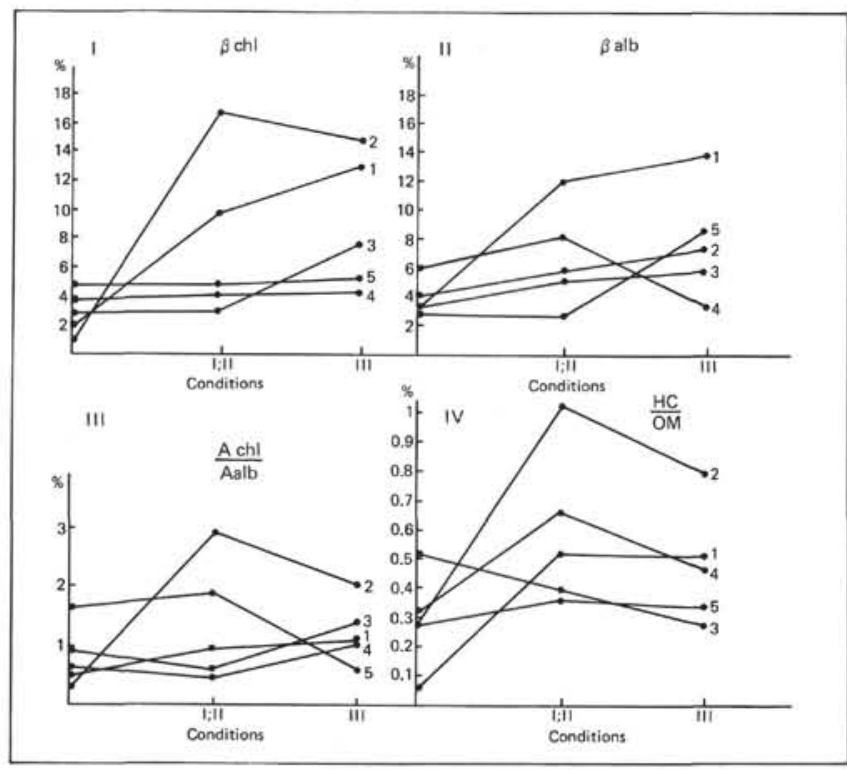

Figure 6. Distribution of separate parameters of bitumoid " $A$ " as dependent on experimental conditions. (I) Sample 5; (II) Sample 35; (III) Sample 47; (IV) Sample 57; (V) Sample 68.

relatively mild thermobaric conditions, separate structures apparently break off with a resulting increase of the hydrocarbon and benzene fractions.

Under more severe experimental conditions (III) when some increase of the content of asphaltenes occurs, the perization processes are apt to prevail over the destructive processes. Such a trend holds for all the samples, with the difference that in some samples these processes occur under milder thermobaric conditions, and, in others, under more severe conditions.

The experimental conditions being equal, the abovementioned differences may be related to the different composition of the initial organic matter and, as a consequence, to the different character of the structures and molecular relationships within individual fractions.

During the heating experiments, not only the quantitative relationships between individual fractions

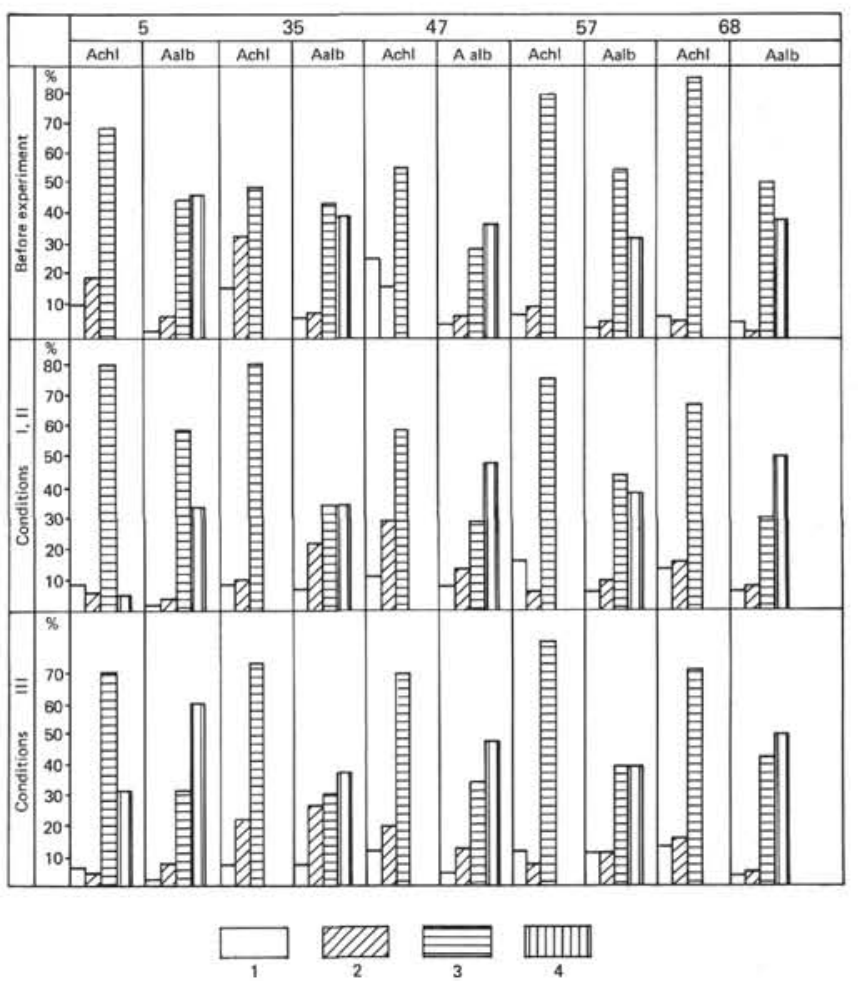

Figure 7. Fractional composition of bitumoid " $A$ " under different experimental conditions. (1) hydrocarbons; (2) benzene resins; (3) alcohol-benzene resins; (4) asphaltenes.

of the bitumoid are noted to change but the structure of these fractions is found to change substantially. Gasliquid chromatography and mass spectrometry show that an insignificant decrease of the content of paraffin hydrocarbons (Sample 68 excluded) in the paraffinnaphthene fraction (Table 13) is accompanied by a 1.52 times increase in $\mathrm{C}_{17}-\mathrm{C}_{24}$ hydrocarbons and isomeric forms. The maxima are found to be somewhat shifted towards the molecules with a smaller number of carbon atoms $\left(\mathrm{C}_{21}-\mathrm{C}_{25}\right)$ (Figure 8$)$. The concentrations of naphthene hydrocarbons and, among the, those of mono-, bi-, and tricyclic structures also increases. 
TABLE 12

Fractional Composition of Bitumoid "A" (simulating samples)

\begin{tabular}{|c|c|c|c|c|c|c|c|c|c|c|c|c|c|c|}
\hline \multirow[b]{2}{*}{ Sample } & \multirow[b]{2}{*}{$\begin{array}{c}\text { Condi- } \\
\text { tions }\end{array}$} & \multicolumn{6}{|c|}{ Achl $(\%)$} & \multicolumn{6}{|c|}{ Aalb (\%) } & \multirow[b]{2}{*}{$\frac{\text { 2 res }}{\text { asph }}$} \\
\hline & & $\mathrm{HC}$ & $\begin{array}{r}\text { Benz } \\
\text { resins }\end{array}$ & $\begin{array}{l}\text { Alc-benz } \\
\text { resins }\end{array}$ & Asph & $\underset{\text { resins }}{\Sigma}$ & $\begin{array}{c}\text { B. res } \\
\text { A-b. res }\end{array}$ & $\mathrm{HC}$ & $\begin{array}{l}\text { Benz } \\
\text { res. }\end{array}$ & $\begin{array}{l}\text { Alc-benz } \\
\text { resins }\end{array}$ & Asph & $\begin{array}{c}\Sigma \\
\text { res- } \\
\text { ins }\end{array}$ & $\frac{\text { Benz. res }}{\text { A-b.res }}$ & \\
\hline 5 & before & 10.00 & 20.00 & 70.00 & - & 90.00 & 0.29 & 2.00 & 7.00 & 45.00 & 46.00 & 52.00 & 0.16 & 1.13 \\
\hline 5 & 1 & 7.32 & 6.10 & 81.70 & 4.88 & 87.80 & 0.07 & 1.74 & 3.48 & 60.00 & 34.78 & 63.48 & 0.06 & 1.83 \\
\hline 5 & III & 4.85 & 3.89 & 71.16 & 30.10 & 75.05 & 0.05 & 1.01 & 7.07 & 32.32 & 60.61 & 39.39 & 0.22 & 0.65 \\
\hline 35 & before & 16.67 & 33.33 & 50.00 & - & 83.33 & 0.67 & 7.35 & 7.35 & 44.12 & 41.18 & 51.47 & 0.17 & 1.25 \\
\hline 35 & II & 8.33 & 10.18 & 81.49 & - & 91.67 & 0.12 & 6.98 & 23.26 & 34.88 & 34.88 & 58.14 & 0.67 & 1.67 \\
\hline 35 & III & 6.12 & 20.41 & 73.47 & - & 93.88 & 0.28 & 6.67 & 26.67 & 29.62 & 37.04 & 56.29 & 0.90 & 1.52 \\
\hline 47 & before & 26.19 & 16.67 & 57.14 & - & 73.81 & 0.29 & 5.00 & 6.67 & 30.00 & 58.33 & 36.67 & 0.22 & 0.63 \\
\hline 47 & II & 11.11 & 29.63 & 59.26 & - & 88.89 & 0.50 & 8.16 & 14.29 & 28.57 & 48.98 & 42.86 & 0.50 & 0.88 \\
\hline 47 & III & 11.29 & 19.35 & 69.36 & - & 88.71 & 0.28 & 4.08 & 12.24 & 34.70 & 48.98 & 46.94 & 0.35 & 0.96 \\
\hline 57 & before & 8.22 & 10.96 & 80.82 & - & 93.78 & 0.14 & 3.90 & 4.68 & 57.04 & 34.38 & 61.72 & 0.08 & 1.80 \\
\hline 57 & 1 & 16.13 & 6.45 & 77.42 & - & 83.87 & 0.08 & 6.25 & 9.38 & 43.74 & 40.63 & 53.12 & 0.21 & 1.31 \\
\hline 57 & III & 11.43 & 8.57 & 80.00 & - & 88.57 & 0.11 & 10.00 & 10.00 & 40.00 & 40.00 & 50.00 & 0.25 & 1.25 \\
\hline 68 & before & 6.94 & 6.25 & 86.81 & - & 93.06 & 0.07 & 4.81 & 2.88 & 51.93 & 40.38 & 54.81 & 0.06 & 1.36 \\
\hline 68 & II & 14.10 & 16.67 & 69.23 & - & 85.90 & 0.24 & 6.78 & 8.47 & 32.21 & 52.54 & 40.68 & 0.26 & 0.77 \\
\hline 68 & III & 12.12 & 16.67 & 71.21 & - & 87.88 & 0.23 & 2.60 & 4.27 & 42.70 & 50.43 & 46.97 & 0.10 & 0.93 \\
\hline
\end{tabular}

It is interesting to note that in all the samples at different experimental conditions a trend towards a decrease of the odd coefficient is apparent (Figure 8), i.e., n-alkanes show more structures with an even number of carbon atoms in a molecule.

Tables 14 and 15 present the results of the IR and UV spectroscopic analyses. As may be seen from the results, during the heating experiments, especially under the severe conditions, there occurs an appreciable increase of aromatic structures in the benzene resins and alcohol-benzene resins represented mainly by naphthalene and anthracene derivatives. Simultaneously, the benzene derivatives become considerably less abundant. A simultaneous increase of the amount of the naphthene-aromatic fragments is noted. Thus, as temperature and pressure grow, the degree of cyclicity and aromaticity in the molecules also grows. These changes are undoubtedly a consequence of the dehydrogenation and dehydrocyclization processes.
The observed increase of the oxygen-containing groups represented mainly by ketones, acids, and ethers of the aliphatic character can apparently be accounted for only by the presence of oxygen from the air in the simulating chamber. However, it is interesting to note that under more severe experimental conditions, the carbonyl groups associated with the aromatic rings appear in the structures of the benzene resins and alcohol-benzene resins.

Based on the UV-spectroscopic data, the initial samples contain rather large amounts of sulfurous organic compounds in the form of sulfides and thiophenes. Their content in the samples under study is dissimilar (Table 15). Under the experimental conditions, their abundance somewhat increases.

\section{CONCLUSION}

The samples studied were found to contain all the constituents encountered in rocks, i.e., hydrocarbons, resins, asphaltenes, insoluble matter. The relationship

TABLE 13

Composition of the Methane-Naphthene Fraction of Hydrocarbons

in Experimental Samples (ratio in \%, based on mass spectrometry)

\begin{tabular}{|c|c|c|c|c|c|c|c|c|c|}
\hline \multirow[b]{2}{*}{ Sample } & \multirow{2}{*}{$\begin{array}{l}\text { Experimental } \\
\text { Conditions }\end{array}$} & \multirow{2}{*}{$\begin{array}{l}\text { Paraffin } \\
\text { Hydro- } \\
\text { carbons }\end{array}$} & \multicolumn{6}{|c|}{ Naphthene Hydrocarbons } & \multirow[b]{2}{*}{ Alkylbenzenes } \\
\hline & & & one-ring & two-ring & three-ring & four-ring & five-ring & six-ring & \\
\hline 5 & before & 52.8 & 14.0 & 5.3 & 12.1 & 5.3 & 3.2 & 2.2 & 5.1 \\
\hline 5 & 1 & 41.8 & 30.4 & 1.0 & 17.1 & 1.5 & 1.3 & 1.0 & 5.9 \\
\hline 5 & III & 51.5 & 10.6 & 7.9 & 19.0 & 1.2 & 2.1 & 1.4 & 5.3 \\
\hline 35 & before & 59.0 & 9.6 & 5.4 & 14.2 & 3.5 & 3.1 & 1.6 & 3.6 \\
\hline 35 & II & 46.9 & 6.2 & 17.8 & 15.3 & 4.1 & 3.3 & 1.4 & 5.0 \\
\hline 35 & III & 46.6 & 14.7 & 8.0 & 17.1 & 5.0 & 2.1 & 1.4 & 5.1 \\
\hline 47 & before & 58.4 & 6.2 & 5.1 & 12.3 & 4.9 & 3.5 & 3.8 & 5.8 \\
\hline 47 & II & 44.2 & 10.6 & 13.5 & 15.2 & 4.1 & 2.6 & 1.2 & 8.6 \\
\hline 47 & III & 48.4 & 13.5 & 8.2 & 18.0 & 3.8 & 2.3 & 1.2 & 4.6 \\
\hline 57 & before & 25.3 & 33.8 & 3.8 & 11.3 & 10.3 & 6.4 & 5.5 & 3.6 \\
\hline 57 & 1 & 20.1 & 35.2 & 3.5 & 15.8 & 7.1 & 3.4 & 2.5 & 12.4 \\
\hline 57 & III & 19.8 & 48.4 & 3.4 & 17.0 & 4.1 & 2.9 & 1.7 & 3.7 \\
\hline 68 & before & 36.9 & 8.3 & 8.0 & 15.2 & 12.4 & 6.5 & 5.3 & 7.4 \\
\hline 68 & II & 52.9 & 9.0 & 5.1 & 16.7 & 5.8 & 4.8 & 2.1 & 4.6 \\
\hline 68 & III & 38.1 & 13.1 & 11.1 & 24.7 & 8.2 & 2.2 & 1.9 & 1.7 \\
\hline
\end{tabular}




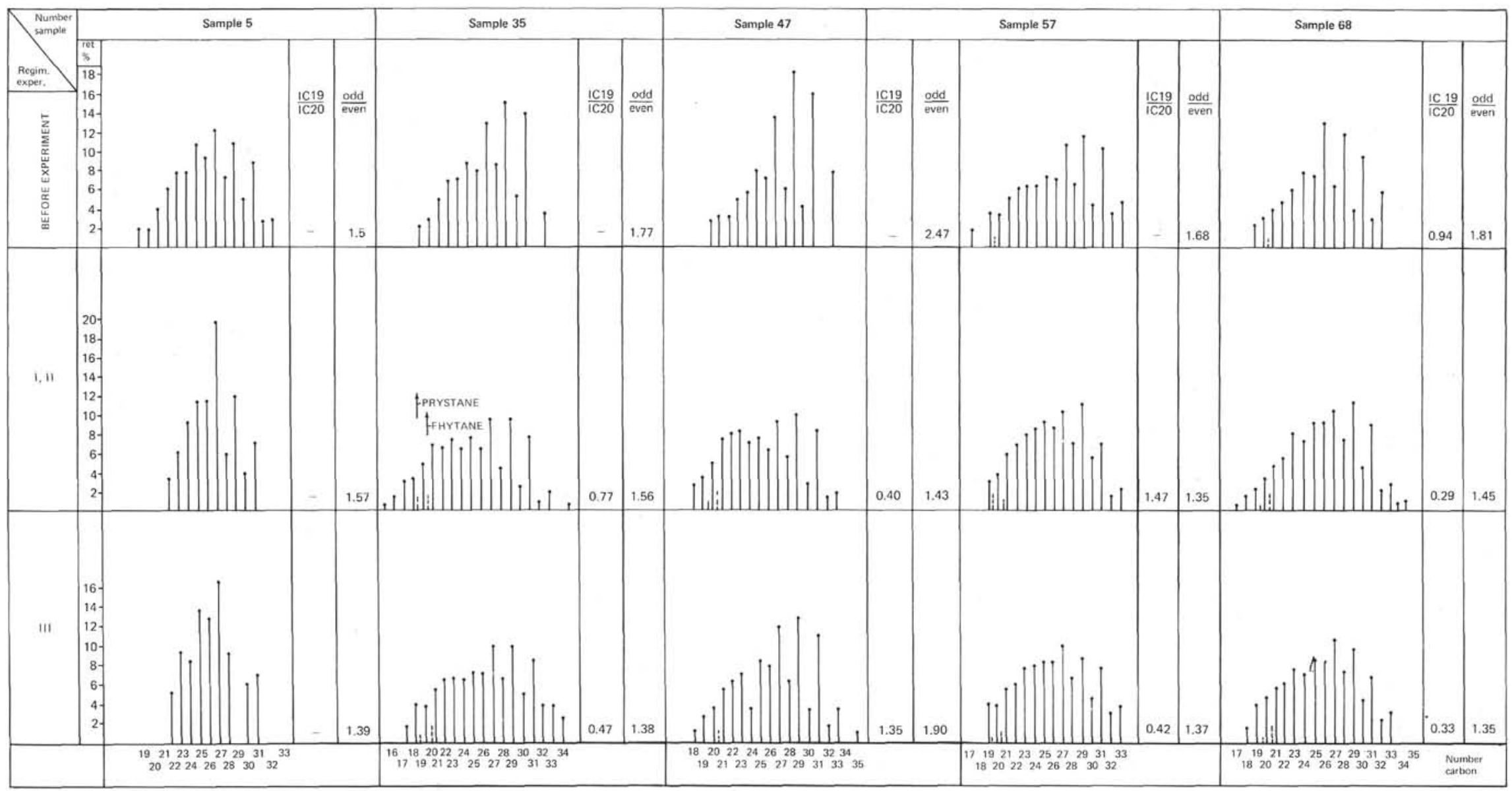

Figure 8. Distribution of normal paraffin hydrocarbons in the methane-naphthene fraction as dependent on experimental conditions. 
TABLE 14

Molar Relationships of Functional Groups in Chromatographic Fractions of Bitumoid Achl (simulating samples)

\begin{tabular}{|c|c|c|c|c|c|c|c|c|c|c|c|c|c|c|c|c|c|}
\hline \multirow{3}{*}{ Sample } & \multirow{3}{*}{ Conditions } & \multicolumn{8}{|c|}{ Benzene Resins } & \multicolumn{8}{|c|}{ Alcohol-Benzene Resins } \\
\hline & & \multicolumn{16}{|c|}{ Absorption $\left(\mathrm{cm}^{-1}\right)$} \\
\hline & & 1740 & 1710 & 1670 & 1600 & 1470 & 1380 & 1115 & 1030 & 1740 & 1710 & 1670 & 1600 & 1470 & 1380 & 1115 & 1030 \\
\hline 5 & before & 0.90 & 1.26 & - & 8.60 & 6.70 & 6.30 & 8.30 & 9.20 & 1.43 & 1.79 & 0.46 & 8.21 & 6.71 & 10.27 & 5.00 & 60.44 \\
\hline 5 & I & 4.50 & 5.93 & 2.90 & 5.90 & 25.10 & 36.50 & 12.15 & 73.60 & - & 3.90 & 0.60 & 17.50 & 73.70 & 5.90 & 2.45 & - \\
\hline 5 & II & 2.17 & 3.04 & - & 20.50 & 16.00 & 15.10 & 5.50 & 21.13 & 2.70 & 4.30 & 0.70 & 5.80 & 62.90 & 7.30 & 3.65 & 6.20 \\
\hline 35 & before & 2.35 & 3.30 & 0.75 & 4.30 & 15.14 & 24.07 & 8.80 & 46.20 & 2.07 & 2.64 & 0.79 & 17.70 & 7.29 & 16.47 & 2.83 & 42.70 \\
\hline 35 & II & 1.90 & 4.50 & 1.30 & 35.20 & 14.30 & 26.20 & 7.70 & 50.40 & 1.60 & 2.10 & 1.00 & 19.50 & 7.10 & 13.20 & 4.80 & 26.40 \\
\hline 35 & III & 3.00 & 5.60 & 1.10 & 23.80 & 12.80 & 17.30 & 6.35 & 30.10 & 1.10 & 3.25 & 0.50 & 9.10 & 6.00 & 9.60 & 2.10 & 9.70 \\
\hline 47 & before & 2.90 & 3.40 & 1.46 & 44.87 & 14.29 & 20.13 & 4.60 & 48.00 & 3.30 & 2.00 & 0.70 & 17.60 & 8.80 & 6.70 & 4.20 & 27.70 \\
\hline 47 & II & 2.10 & 3.39 & 1.50 & 29.80 & 12.60 & 20.10 & 6.70 & 46.90 & 0.70 & 4.50 & 1.00 & - & 7.70 & 16.00 & 8.10 & - \\
\hline 47 & III & 3.20 & 4.00 & 1.25 & 44.90 & 17.60 & 27.70 & 6.50 & 63.30 & 0.60 & 1.80 & 0.34 & - & 5.00 & 6.20 & 16.00 & 89.20 \\
\hline 57 & before & 2.75 & 5.01 & 1.25 & 56.62 & 18.90 & 28.30 & 7.00 & 6.00 & 1.00 & 1.40 & 0.30 & 3.60 & 4.10 & 5.70 & 1.30 & 5.00 \\
\hline 57 & I & 3.00 & 5.70 & 0.95 & 23.80 & 17.10 & 28.00 & 3.60 & 44.60 & 2.75 & 3.60 & 1.00 & 15.90 & 9.40 & 14.70 & 6.00 & 36.40 \\
\hline 57 & III & 0.50 & 0.75 & 0.35 & 11.70 & 3.40 & 5.00 & 3.10 & 59.70 & 5.10 & 7.25 & 1.80 & 31.60 & 19.60 & 27.60 & 12.30 & 61.70 \\
\hline 68 & before & 1.28 & 1.60 & 1.67 & 20.90 & 8.40 & - & 6.60 & 22.40 & 0.75 & 1.20 & 0.35 & 6.40 & 3.00 & 5.20 & 0.90 & 4.90 \\
\hline 68 & II & 2.10 & 1.70 & 0.80 & 15.50 & 9.60 & 12.70 & 4.20 & 16.60 & 0.80 & 1.10 & 0.35 & 8.90 & 3.10 & 5.10 & 2.10 & 10.60 \\
\hline 68 & III & 2.80 & 3.25 & 1.30 & 31.10 & 13.40 & 18.40 & 6.00 & 39.30 & 1.20 & 2.50 & 0.45 & 8.60 & 4.30 & 7.10 & 2.90 & 17.90 \\
\hline
\end{tabular}


TABLE 15

Relative Content of Aromatic Structures in Resins of Bitumoid "A" Based on UV-Spectroscopic Data (internal standard) (simulating samples)

\begin{tabular}{|c|c|c|c|c|c|c|c|c|c|c|c|}
\hline \multirow[b]{2}{*}{ Sample } & \multirow[b]{2}{*}{ Conditions } & \multicolumn{5}{|c|}{ Benzene Resins } & \multicolumn{5}{|c|}{ Alcohol-Benzene Resins } \\
\hline & & Sulfides & $\begin{array}{l}\text { Achl } \\
\text { Thio- } \\
\text { phenes }\end{array}$ & $\begin{array}{l}\text { Naphtha- } \\
\text { lenes }\end{array}$ & Benzenes & $\begin{array}{l}\text { Anthra- } \\
\text { cenes }\end{array}$ & Sulfides & $\begin{array}{l}\text { Thio- } \\
\text { phenes }\end{array}$ & $\begin{array}{l}\text { Aalb } \\
\text { Naphtha- } \\
\text { lenes }\end{array}$ & Benzenes & Anthracenes \\
\hline 5 & before & 1 & 1 & 1 & 1 & 1 & 1 & 1 & 1 & 1 & 1 \\
\hline 5 & I & 2.5 & - & 2.5 & 2.8 & 2.8 & 1.7 & - & 1.8 & 1.75 & 1.75 \\
\hline 5 & III & 7.5 & - & 5.0 & 7.3 & 7.3 & 2.1 & - & 1.3 & 1.4 & 1.3 \\
\hline 35 & before & 1 & 1 & 6.0 & - & 1 & 1 & - & 1 & - & 1 \\
\hline 35 & II & 0.3 & 0.6 & 0.5 & - & 1.3 & 0.55 & - & 0.8 & - & 2.2 \\
\hline 35 & III & 0.06 & 0.2 & 0.09 & - & 1.4 & 0.8 & - & 0.7 & - & 2.1 \\
\hline 47 & before & 1 & 1 & 1 & 1 & 1 & 1 & - & 1 & - & 1 \\
\hline 47 & II & 1.2 & 1 & 0.75 & - & 1.1 & 10 & - & 7 & - & 4.8 \\
\hline 47 & III & 0.56 & 0.4 & 0.4 & - & 0.4 & 14 & - & 8.6 & - & 3.5 \\
\hline 57 & before & & & & & & 1 & 1 & 1 & 1 & 1 \\
\hline 57 & I & & & & & & 0.8 & - & 0.3 & 0.2 & 0.65 \\
\hline 57 & III & & & & & & 0.8 & - & 0.4 & 0.4 & 1.4 \\
\hline 68 & before & & & & & & 1 & - & - & - & - \\
\hline 68 & II & & & & & & 0.6 & - & 0.7 & - & - \\
\hline 68 & III & & & & & & 0.9 & - & 0.7 & - & - \\
\hline
\end{tabular}

between these constituents, their structure and properties depend to a great extent on the initial organic matter, on the conditions, and the degree of its transformation.

The experimental simulation revealed that accumulation of the light hydrocarbon fraction and heavy hydrocarbon gases occurs simultaneously with the formation of condensed aromatic and naphthene- aromatic structures resulting from hydrogen disproportionation.

The general picture of the evolution in the formation of hydrocarbons as a result of the catagenic transformation of organic matter based on the natural material corroborates the major existing concepts and is indicative of the organic origin of oil and gas in nature. 